\title{
Special Issue on Materials in Demanding Environments
}

DOI:

10.1016/j.jimecsci.2018.07.009

\section{Document Version}

Accepted author manuscript

Link to publication record in Manchester Research Explorer

\section{Citation for published version (APA):}

Jivkov, A., \& Sedighi, M. (2018). Special Issue on Materials in Demanding Environments. International Journal of Mechanical Sciences, 144, 813-813. https://doi.org/10.1016/j.ijmecsci.2018.07.009

\section{Published in:}

International Journal of Mechanical Sciences

\section{Citing this paper}

Please note that where the full-text provided on Manchester Research Explorer is the Author Accepted Manuscript or Proof version this may differ from the final Published version. If citing, it is advised that you check and use the publisher's definitive version.

\section{General rights}

Copyright and moral rights for the publications made accessible in the Research Explorer are retained by the authors and/or other copyright owners and it is a condition of accessing publications that users recognise and abide by the legal requirements associated with these rights.

\section{Takedown policy}

If you believe that this document breaches copyright please refer to the University of Manchester's Takedown Procedures [http://man.ac.uk/04Y6Bo] or contact uml.scholarlycommunications@manchester.ac.uk providing relevant details, so we can investigate your claim.

\section{OPEN ACCESS}




\section{Accepted Manuscript}

Special Issue on Materials in Demanding Environments

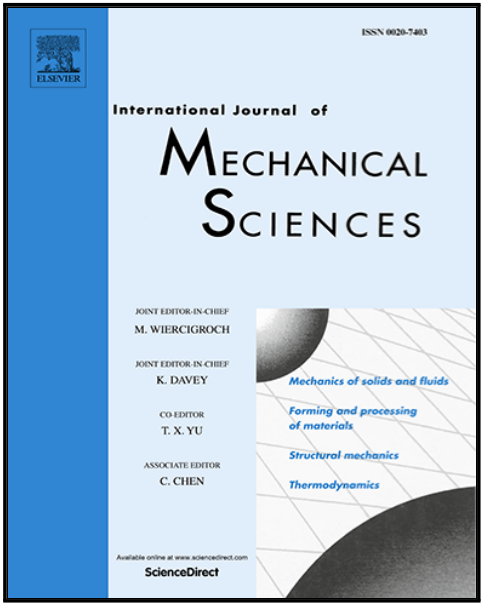

To appear in:

International Journal of Mechanical Sciences

Please cite this article as: Andrey P. Jivkov, Majid Sedighi, Special Issue on Materials in Demanding Environments, International Journal of Mechanical Sciences (2018), doi: 10.1016/j.jmecsci.2018.07.009

This is a PDF file of an unedited manuscript that has been accepted for publication. As a service to our customers we are providing this early version of the manuscript. The manuscript will undergo copyediting, typesetting, and review of the resulting proof before it is published in its final form. Please note that during the production process errors may be discovered which could affect the content, and all legal disclaimers that apply to the journal pertain. 
Special Issue on Materials in Demanding Environments.

Andrey P Jivkov ${ }^{1}$ and Majid Sedighi ${ }^{1}$

School of Mechanical, Aerospace and Civil Engineering, The University of Manchester, Sackville Street, M13 9PL

This issue offers a selection of 12 scientific papers that describe advances in modelling and testing the complex behaviour of engineering metallic and non-metallic materials in demanding environments. The collection displays how the current understanding of materials degradation mechanisms is translated into coupled physical, chemical and mechanical models. The majority of articles are extended papers from two mini symposia organised as part of the $12^{\text {th }}$ World Congress on Computational Mechanics (WCCM XII) and The $6^{\text {th }}$ Asia-Pacific Pacific Congress on Computational Mechanics (APCOM VI) in July 2016. The two mini-symposia were: (1) "Materials in Demanding Environments: Modelling the Coupled Degradation Mechanisms" organised jointly by Majid Sedighi and Andrey P Jivkov (The University of Manchester, UK), and Philip J Vardon (Delft University of Technology, Netherlands); and (2) "Advanced Materials: Computational Analysis of Properties and Performance" organised by Vadim V Silberschmidt (Loughborough University, UK) and Valery $P$ Matveenko (Perm State University, Russia).

In relation to metallic materials, Harichandran and Selvakumar present research on microstructure and mechanical characterization of aluminium hybrid nanocomposites processed by ultrasound assisted casting. The influence of micro grooves on the parameters of a centrifugal pump impeller is discussed by Skrzypacz and Bieganowski, with a focus on the impact of microgeometry on the efficiency of centrifugal pumps with extremely low specific speed. Thermal conductivity and mechanical properties of ZrxCu90-xAl10 under tension are studied using molecular dynamics simulations by Nath. Anani and Rahimi present a solution for an axisymmetric thick shell composed of a functionally graded incompressible hyper-elastic material.

A couple of studies describe the modelling of material cracking and crack propagation. The Influence of grain boundary sliding near a nanovoid on crack growth in deformed nanocrystalline materials is studied by He at al. Gironacci et al. describe a nonlocal probabilistic method for modelling crack propagation.

In relation to non-metals, several papers focus on the effects of temperature on cement-based materials. Coupled degradation mechanisms of cementitious materials exposed to cold climates are presented by Panesar. Torreli et al. present a study on the behaviour concrete at elevated 
temperatures up to $500{ }^{\circ} \mathrm{C}$ by developing a confinement-dependent load-induced thermal strain constitutive model. Estabragh et al. present a study on the effects of heating and surfactant treatments on the engineering properties of cohesive soils. Yu et al. present a study on the effect of capillary connectivity crack density on the diffusivity of cementitious materials.

In the area of emerging materials, Pang et al. present a study on indentation in single-crystal $6 \mathrm{H}$ silicon carbide for small-scaled devices deployed in demanding environments through experimental investigations and finite element analysis. In the area of structural dynamics, Zhang et al.present a novel technique to predict the harmonic response of particle-damping structures.

We are grateful to all contributors for their efforts in preparing the manuscripts and for their patience during the review process. Finally, thanks are extended to Keith Davey, the /JMS Editor-inChief for supporting the special issue on Materials in Demanding Environments from its inception to final publication. 